\title{
Sultan Ahmad: The Dilemma between the Local Rebels and British Colonialists in Pahang at the End of the $19^{\text {th }}$ Century
}

\author{
Wan Kamal Mujani ${ }^{1}$,Amnah Saayah Ismail ${ }^{2}$, Izziah Suryani Arsyad @ Mat $\operatorname{Resad}^{1}$ \& Norshima Zainal Shah ${ }^{3}$ \\ ${ }^{1}$ Faculty of Islamic Studies, Universiti Kebangsaan Malaysia, Bangi, Malaysia \\ ${ }^{2}$ Faculty of Defence and Strategic Studies, National Defence University of Malaysia, Kuala Lumpur, Malaysia \\ ${ }^{3}$ Language Centre, National Defence University of Malaysia, Kuala Lumpur, Malaysia \\ Correspondence: Wan Kamal Mujani, Department of Arabic Studies and Islamic Civilization, Faculty of Islamic \\ Studies, Universiti Kebangsaan Malaysia, 43600 Bangi, Selangor, Malaysia. Tel: 60-3-8921-5552. E-mail: \\ inamal@yahoo.com
}

Received: October 18, 2013

Accepted: November 25, 2013 Online Published: January 27, 2014

doi:10.5539/ass.v10n3p205

URL: http://dx.doi.org/10.5539/ass.v10n3p205

\begin{abstract}
British colonization over the state of Pahang in the late $19^{\text {th }}$ century resulted in an incident which is known as the Pahang uprising. Introduction of several new systems by the colonialists had caused chaos. The locals, mostly the dignitaries or chieftains who were in close relationship with the Sultan, rebelled against these new enforcements. On the other hand, the Sultan who had to maintain his status quo with the British was in a dilemma. This article looks at the dilemma faced by the ruler and how he maneuvered the crisis; through thorough content analysis of available literature. It is found that Sultan Ahmad was very intelligent, wise and diplomatic in preserving peace and harmony amongst the local people and could still be in the good books of the British. His strategies united the rebels yet he maintained his sovereignty and remained unthreatened by the British.
\end{abstract}

Keywords: Sultan Ahmad, rebels, British colonization, diplomacy, strategy

\section{Introduction}

The riots that happened upon British intervention in Pahang in the $19^{\text {th }}$ century put Sultan Pahang in the limelight. His every step and movements were monitored by the colonialists to check on the Sultan's involvement in the upheavals. The people of Pahang who looked upon the Sultan, was also in a confusion of which side their Sultan was on; theirs or the colonial power? The authors opine that the Sultan was indeed a meticulous and intelligent man and treaded the acute situation carefully. The locals were initially disappointed seeing the Sultan supported the British by offering rewards for the capture of the rebels. Eventually they understood it was a ploy to divert the attention of the British and as a strategy to chase the colonialists out of the state of Pahang. The successions of many discontentments between the locals and the British put the ruler in a dilemma. The dilemma could be seen when the Sultan had to opt between two: the colonial power and Dato' Bahaman, his trusted local chief. The authors posit that the Sultan cunningly deceived the British through his well-planned strategies in supporting and covering up the local rebels. The British on the other hand were skeptical and wary of the Sultan's moves as they were unsure of his support (Reid, 1967).

\section{Sultan Ahmad}

Bendahara Wan Ahmad was officially elected as Pahang state ruler by the Pahang dignitaries. He was the first sultan from the descendants of former traditional judges (Bendahara).The practice of appointing the sultan from the descendants of traditional judges started with the death of Bendahara Tun Ali who was then replaced by Tun Muthahir in 1857; who ruled the throne until 1863. It was during the reign of Tun Muthahir that a civil war erupted between him and his brother, Tun Ahmad. The internal conflict took ages to settle, and as a result of the war, the period of time in the middle of the $19^{\text {th }}$ century was wasted when they could have utilized the period to enforce stability and power in the state of Pahang. The quarrel between the two brothers ended with a victory for Tun Ahmad who was later appointed as the sultan with the title Bendahara Ahmad in 1863. He was later proclaimed as Sultan Ahmad on the $6^{\text {th }}$ of August 1882. The coronation ceremony for Sultan Ahmad was held on the $12^{\text {th }}$ of December 1884 where he was appointed as Sultan Ahmad al-Muazzam Shah Ibn al Marhum 
Bendahara Ali (Roff, 1967).

\section{Sultan Ahmad's Predicament: Local Rebels and the Colonial Power}

Sultan Ahmad covert involvement in helping the rebels led by Dato' Bahaman started the day Dato' Bahaman was ripped off the title Orang Kaya Setia Perkasa Pahlawan Semantan. This was the first time someone ever so close to the sultan was being demoted. Dato' Bahaman was relieved of his post as the leader of Semantan. This is one of Sultan Ahmad's strategies which the British could not predict. The colonial power felt that Sultan Ahmad was diligently following orders from them to dismiss Dato' Bahaman because he was a stubborn leader.

Aruna Gopinath (1993) has beautifully and precisely described this issue. He posited that even though the demotion of Dato' Bahaman's post was seen as a cooperation and agreement between Sultan Ahmad and the British, this was not so as it was actually a well-planned strategy. Legally, Sultan Ahmad demoted Dato' Bahaman on the advice from Tengku Mahmud as the middle person between him and the British. Sultan Ahmad was truly confident that Dato' Bahaman was the only person who could go against the British openly and armed. All these actions were taken to restore the Malay traditional ruling power taken by the colonialists.

Sultan Ahmad knew Dato' Bahaman personally since small and was sure of Dato' Bahaman's prowess and abilities to openly go against the British. The Sultan was also confident that Dato' Bahaman will not defy his position as the legitimate ruler of the Pahang state. Thus Sultan Ahmad pretended to agree to all requests made by the British to fight against Dato' Bahaman. The Sultan posted a notice along the roads in Pekan warning the public that "Bahaman is a traitor and could not be trusted". The chieftains also supported the Sultan and pictured Dato' Bahaman as "A person who is difficult to negotiate with because of his obvious stupidity" (Pahang Annual Report, 1891; C.O 273/179).

Nevertheless, Sultan Ahmad's confidence towards Dato' Bahaman in his efforts against the British was kept secret so much so his actions were not detected by the British colonialists. His actions were sometimes pro Dato' Bahaman yet at other times sided with the British. This is also seen as a plot against the British in regaining his ruling power.

The moment the uprising started, Sultan Ahmad did not show his support for the British. In addition, the Sultan gave minor reasons to convince the British that he did not have the intention to quash the rebellion on his own effort. The Sultan was saved for a period of time when there was a flood in Pahang in January 1892. Consequently, the Sultan showed his disagreement for the British when he did not want to accept help from Selangor. His reasons were personal when he was really angered with Saiyid Mashur who was involved in the civil war during mid- $19^{\text {th }}$ century in Pahang.

Saiyid Mashur's presence was made the reason to why the Sultan did not want to cooperate with the British in the effort of defeating the rebellion in Pahang at that time (C.O 273/179; Middlebrook, 1983). However, the presence of the Selangor people was favored by Dato' Bahaman because to him this will benefit the rebels. The Selangor people will be absorbed into the military troop in attacking and later on take control of all major centers in Pahang. There were some incidents which showed Sultan Ahmad's negative relationship with the British in curbing the rebellion. At the point, the British started to doubt and suspect the Sultan of working with the rebels due to his uncooperativeness.

Hence to avoid disorder and the British's suspicion of the relationship between the Sultan and the rebels, Sultan Ahmad started to plot his strategies. On the $29^{\text {th }}$ of December 1891, the Sultan sent Tengku Mahmud, a few leaders and 200 followers along with Sir Clifford and Inspector Summer, and 60 Sikh policemen to Kuala Semantan (Pahang Annual Report, 1891). At the very time, there was an order by Sultan Ahmad to capture the increasingly savage rebels and the prize offered was in terms of cash money. The sultan's action has successfully won back the British's trust and wipe out the presumption of the cooperation between the Sultan and the rebels. This action also convinced the British that the ruler strives to prevent the rebellion that has erupted in Pahang. The monetary reward offered by the Sultan is similar to what was done in Perak upon the execution of JWW Birch. The Sultan was convinced that this action will succeed as in Perak.

Sultan Ahmad's actions in his effort to show support of the British was accepted partially. The Sultan himself realized that he had to do something in order to prevent the uprising from continuously spreading. Likewise, the British were confident that they should maintain the Sultan's position as a ruler to defeat the rebels. The British confidence was also based on the belief that the Sultan is a sovereign and was well looked upon by the people. In addition, another factor for the Sultan to be maintained as the ruler is the increased awareness of the people on the bad effects of British denomination over Pahang. The retention of the Sultan's title was seen to prevent threat from local people despite the presence of local people who were not in favor of the Sultan; the number is very 
minimal.

The reasons forwarded by the British to influence the Sultan in the effort of stopping the rebellion were welcomed well by the Sultan. The Sultan believed that this situation would clear the perception that he was involved as a strong supporter to the rebels. The Sultan was also aware that if he refused to acknowledge and deny the invitation from the British, it will initiate a bigger disaster. Hence, as a reaction to the situation, the Sultan wrote to Governor Smith saying that he has agreed and ready to go against the local rebels. However, as a condition to his approval, the Sultan wanted to be only with his men if weapons were supplied to them (C.O 273/179).

The British agreed with Sultan Ahmad's request and he led his followers to Pulau Tawar on the $14^{\text {th }}$ of January 1892 to defeat the rebels. Consequent to this, the fight against the rebels started on the $22^{\text {nd }}$ of January 1892 with the help of Tengku Ali, Rodger, Panglima Garang Yusuf and Abdullah from Bera. The number of his followers is approximately 500 people (C.O 273/179). Sultan Ahmad's troop successfully destroyed 12 of Dato' Bahaman's forts and Dato' Bahaman had to seek safety in the jungle. This situation made the British extremely happy and Sultan Ahmad's hidden intentions and his opinion of Dato' Bahaman were well camouflaged.

Sultan Ahmad's actions were part of his strategies to deceive the British in thinking that he is loyal to them and avoid them from thinking he has betrayed them. His well preparedness was based on the fact that he wanted to maintain his sovereignty apart from not wanting to be demoted by the British. Like Dato' Bahaman, the Sultan too wanted to chase out the colonialists and prevent them from conquering his homeland. Although the Sultan was closely monitored by the British including by Rodger, yet the colonialists were still puzzled and unsure of his true hidden intentions. The local dignitaries and the people of Pahang too were unable to identify their Sultan's plan where some of them were really disappointed when the Sultan showed his support towards the British by joining the group to go against the local rebels (Gopinath, 1993).

Sultan Ahmad continued to support and cooperates with the British until January 1892. The Sultan did not take any action to defeat the rebels until he was asked to help by the British. The Sultan abided by the agreement made in 1891 at Pulau Tawar and he had to please the dignitaries according to the agreement (C.O 273/182). The British worries of the rebellion being instigated by Sultan Ahmad was proven true when Dato' Bahaman with his cunning ability successfully gathered military forces using the Sultan's name and received weapon supplies from Tengku Ali (Straits Settlement Records India Office, 1892).

Here, Dato' Bahaman's loyalty to Sultan Ahmad has been proven. Dato' Bahaman did not involve the Sultan but in another situation, the Sultan has supported the rebellion and Dato' Bahaman throughout the state. Due to the cooperation between Sultan Ahmad and Dato' Bahaman, the Semantan state fell into the rebels' hand easily. The cooperation is to revive the pre-colonial power snatched by the British from them. Therefore Sultan Ahmad did not show any interests to end the rebellion. His support towards the rebels could not be doubted as he claimed that the British has taken over the government administration from him. This has resulted in mayhem hence it was not his business to solve the problem initiated by the colonialists (Gopinath, 1993).

\section{Reasons Used by Sultan Ahmad}

Sultan Ahmad has invoked various excuses to deceive the British to convince them that he was unable to stop the rebellion thoroughly. Among the reasons used by the Sultan were, the absence of support from state dignitaries and the people were not loyal anymore to him as he was being replaced by the Resident. But at the same time the Sultan claimed of his loyalty to the colonialists by giving his commitment to all the directives or orders from the British. As an example, the Sultan listened and agreed to the pardon given to the rebels provided that they returned to their villages within a month of their capture. The pardon was on Rodger's instruction. The British was happy with the Sultan and were less suspicious of his loyalty towards them.

In addition, a reward for $\$ 1000$ was announced for the capture of the rebels. This was seen as an incentive for the surrender the rebellion leader (Pahang Annual Report, 1891). Sultan Ahmad received the directive well. At that moment Sultan Ahmad supported the British. They began to prepare for the administration for Semantan and Temerloh. New leaders were elected with the hope that the British will not interfere with the administration while they work to curb and stop the rebellion earlier than expected. But the opposite happened when a leader they elected, Che Abdullah who was in charge of Lubuk Terua allowed his people to return to Bera and chased out people from Kampung Chempaka and Bola who sympathized and sided with Dato' Bahaman. This situation gave advantage to Dato' Bahaman and he easily took over Lubuk Terua on the $9^{\text {th }}$ of March 1892.

When Lubuk Terua was captured by Dato' Bahaman, Sultan Ahmad returned to Pulau Tawar. The Sultan was once again called to fight and curtail the rebellion that was happening then. This time, the Sultan refused to 
follow British orders giving the reason that it was the month of Ramadhan when the Muslim people are fasting. Ramadhan coincidently started on the 24th of March 1892 (C.O 273/180). The Sultan did not show any clear intention or actions in curbing the rebellion. The fight against the colonialists became stronger. At the same time, local dignitaries started to favor and support Dato' Bahaman and his followers.

The British never thought that the local dignitaries will betray them by joining Dato' Bahaman. Tok Raja Jelai, Tok Gajah, Tok Bandar and their followers were loyal right hand men to the Sultan. Their support for Dato' Bahaman was seen as a way to chase the British out of the state. British were seen as a political threat that needed to be evicted and chased away to preserve traditional power. This situation is also seen as the start of local anti-colonization movement.

\section{Anti Colonization Opposition}

The anti-colonial movement was evident in the murder of Stewart and Harris from the Pahang Exploration Company. Both of them were killed by Panglima Muda at Sungai Duri. This murder conspiracy was connected to Sultan Ahmad as revealed by Panglima Muda himself as the person who executed the murder order included Tok Gajah as the middle man. Apart from that there was a report stating that the killing happened on the order from Tok Gajah. Sultan Ahmad was concerned with these happenings as he was afraid he would be accused and made responsible. The Sultan pretended of not knowing about the killings and denied knowing Panglima Muda as the title was conferred by the late Bendahara Kuris. The Sultan also proclaimed that he had never given any power to Panglima Muda in his administration (C.O 273/180).

Sultan Ahmad's denial was not accepted as Panglima Muda showed Sultan Ahmad's stamp as proof of the Sultan's involvement in the killings of Stewart and Harris. At that moment, more local dignitaries started to support the rebels in secrecy in order not to be detected by the colonialists. All of them including Sultan Ahmad himself acted as if they fully supported the British but actually were strongly for the rebels. For example, Sultan Ahmad himself has instructed Orang Kaya Chenor who was Panglima Muda's man to capture Panglima Muda. This is an impossible task which was unlikely to happen because during those days, people are loyal to their leaders (C.O 273/183).

At the same time, Sultan Ahmad continued to show full support to the British by attacking Dato' Bahaman and his followers. The support was also pledged through a letter dated $23^{\text {rd }}$ February 1892 asking Tok Raja to join the discussion in curbing the rebellion. The Sultan also stated that he would not put up an arms struggle against the British. This situation was related to Tok Raja's plans; Tok Raja collaborated with Tok Gajah where both of them arranged the attack on the government armed forces in Hulu Pahang. The plans were made so that the Sultan could conquer Chenor and Panglima Muda Jempul could conquer Pekan. Meanwhile Tok Gajah ordered the Tembeling people to unite with Tok Raja and instructed Tok Raja to attack Kuala Lipis. The Sultan's declaration made the dignitaries very angry especially Tok Raja and they assumed that the Sultan was closely associated to the British and could not be trusted. The dignitaries concluded that the Sultan was dishonest with the local people.

However, in the writers' opinion, these are safety measures taken by Sultan Ahmad to deflect British suspicions towards him. Aruna Gopinath (1993) provides an orderly deliberation in answering the question of Sultan Ahmad's pro-British stance and loyalty at that time so much so that he cancelled the plan to attack Kuala Lipis which was mooted by Tok Raja and other dignitaries. The British warned Sultan Ahmad that he will be made responsible if he fail to act on the Stewart and Harris murder. The pressure by the British was meant to coerce Sultan Ahmad to exercise his power to stop the disturbances. It is also a ploy by the British to use Sultan Ahmad and other dignitaries to influence the rebels to end their rebellion which was at the peak and spreading throughout the state. Due to the warnings and pressure, Sultan Ahmad was forced to bow to the British although deep inside he is very keen and determine to expel the British from the state.

He is seen to be loyal to the British but the fact is, he sympathizes with the rebels. The writers opined that it was a smart diplomatic ploy to ensure the safety of his people even though some may suggest that it was to protect his own position. The writers however are confident that steps taken by the sultan and other dignitaries were part of their hidden agenda to expel the British from Pahang.

Sultan Ahmad continued to show his unwavering support for the British. Due to the continued uprising the $\$ 1000$ reward was maintained as an incentive to quash the rebellion. The other dignitaries were vengeful of the sultan which resulted in the attack and killing of three of the sultan's followers. Sultan Ahmad was forced to alter his approach by pacifying the rebels and at the same time continuing his support for the British forces. He took 1000 of his men to Semantan for the second time where a small battle took place in Batu Ampar under the disguise of hunting down one of Dato' Bahaman's son and to show the British that he was behind them in 


\section{suppressing the rebellion.}

\section{Sultan Ahmad's Change of Attitude}

Contrary to his previous stance, Sultan Ahmad appeared to have an apparent dislike and hatred towards the Sikhs and Europeans. He was adamant that the Sikhs and Europeans should not follow him as their presence might result in Dato' Bahaman and his men staying away from him as with what happened in the first movement (C.O 273/184). His excuse in not allowing the Sikhs and Europeans to follow him is actually meant to help the rebels as he knew that the loyalty of the Sikhs and Europeans towards the British would jeopardize his plan. The Sultan was accompanied by Tengku Ali, Tok Gajah, Orang Kaya Chenor and Orang Kaya Temerloh this time around. In Lubuk Terua, the Sultan and the other dignitaries supplied food to Dato' Bahaman. Dato' Bahaman wrote to the Sultan and confessed that the rebellion was ignited by him with the supply of arms by Tok Raja. Rodger grew increasingly wary and suspicious of Sultan Ahmad's 'two-faced' attitude. The second movement failed due to the brilliant manipulation of the situation by Sultan Ahmad. Sultan Ahmad together with Tok Gajah left Temerloh for Pulau Tawar on $22^{\text {nd }}$ June 1892. The crisis was aggravated when some of the dignitaries became disillusioned with the motives and policies of Sultan Ahmad resulting in the murder of Orang Kaya Chenor whilst fighting the rebels. The Sultan himself faced a greater hurdle when he was asked to move to Pekan as the British suspected the Sultan of being involved in the supply of food and arms to the rebels. The British thought that by moving the Sultan to Pekan, it would erode his influence, bring about a change of attitude, and prevent further tarnishing of his reputation and his relationship with dignitaries from Hulu would be put to a stop (C.O 273/182).

By moving Sultan Ahmad to Pekan, the British hope that it will defuse their concern of the Sultan's support for the rebels. It was far from over when Tok Gajah, the Sultan's most senior dignitary and follower sided with the rebels. This has become a nightmare to the British and soon they plotted to counter Tok Gajah's activities with the help of the Sultan in Pekan. Tok Gajah was suspected of conspiring with Mat Kilau in the attack in Budu and he was put on the British wanted list. The Sultan under the pretext of helping the British; proposed for Tok Gajah to be brought to Pekan and subsequently deported him to Mecca. The proposal was agreed by the British, not knowing that the Sultan has his own plan of allowing Tok Gajah to slip away to Kelantan via Tembeling. He then returned to Pekan so as to avoid further suspicion by the British which is in line with his previous statement to return to Pekan if he was unable to quash the rebellion and the responsibility will then fall on the government to act on its own using its own forces (C.O 273/184).

The Sultan's action, in the opinion of the writers was intended to satisfy both parties. His agreement to attack Semantan, bringing Tok Gajah to Pekan and deport him to Mecca was meant to please the British and at the same time hide his own plan. To expel the British forces equipped with modern arms who kept a close watch on his movement is a mounting task and would need a well prepared plan. The writers opined that it was a brilliant and well thought out plan by the Sultan to evade the British suspicion of him supporting the rebels. Even though his dislike towards the Sikhs and Europeans was seen as anti-colonial, he was able to convince the British that it was a tactic to get close to the rebels and to facilitate negotiations with the rebels even though from the letter written by Dato' Bahaman, it was clear that the rebellion was started on his order. Another example of his brilliance is the delay in apprehending Tok Gajah. His reasons and excuses were accepted by the British and this proved that he exercised great diplomacy in the most critical situations. It was due to his brilliance that Tok Gajah and his followers were able to evade capture.

However Sultan Ahmad's intention of declaring an open opposition towards the British did not materialize even when Tok Raja, Tok Gajah and Dato' Bahaman were united. This is due to the fact that Sultan Ahmad was bounded by the 1888 treaty and his concern of being expelled if he failed to follow British orders. The Sultan maintained a smart but cautious with the British. The British burned the Sultan's palace in Pulau Tawar as a means of severing the relationship between the Sultan and the rebels. Sultan Ahmad later took residence in Lenyah (C.O, 273/182). The action by the British was seen by Sultan Ahmad as suppression in making him follow British orders in any situation. This event marked the end of the first phase of the Pahang rebellion.

\section{British Restrictions Weaken Sultan Ahmad's Role}

In the second phase of the Pahang rebellion, Sultan Ahmad's involvement was not clearly visible. This is due to the many restrictions imposed upon him by the British since the early period in the first phase which resulted in his inability to provide support for the rebels. In the second phase where the struggle was seen as a Islamic religious duty, Sultan Ahmad decided to be involved directly in the struggle especially after learning about the rebel's victory in Kuala Tembeling and the British's victory in Jeram Ampai. His decision to get involved in the struggle is to impress upon the British that he was intent on maintaining peace. Sultan Ahmad however was once again influenced by Sultan Abu Bakar of Johor in July 1894 who advised him of siding with the British forces. 
Sultan Ahmad agreed to this but he was closely watched by the British as the British were suspicious that he would leak vital information to the rebels in their plan to capture the rebels. These are sequences of the influence and role of Sultan Ahmad which the British deemed as the inner force in helping the rebels.

\section{Conclusion}

Based on Sultan Ahmad's reactions as discussed earlier, the writers opine that although Sultan Ahmad's help and support for the rebels in these two phases seem limited, they are still worthy as Sultan Ahmad was still accepted by the British. This is due to the fact that the British saw Sultan Ahmad's sovereignty as a traditional ruler is very useful in bringing down the rebels in Pahang. Sultan Ahmad's wisdom is highlighted in his diplomacy with the colonialists where he successfully closed any door to cooperate with them yet was able to support the rebels. The Sultan's concern upon Dato' Bahaman and his followers denotes his own wish to chase the British out of Pahang and can be seen from his support. Reasons after reasons were given just to stall the colonialists and make time for the rebels to hide themselves. This is also a way to show his love to his people. Yet the decision to burn down his castle in Tawar Island resulted in the Sultan having to follow the British order even though the burning of the castle intentionally was to keep the Sultan and the rebels apart. The colonialists cunningly strategies were coherent to Sultan Ahmad's and his dignitaries' diplomacy in helping the rebels. Even though in the first rebellion, it looked as if they were supporting the British, somewhat it succeeded in displaying the anti-colonization of the Pahang people against the colonialists.

\section{Acknowledgements}

Research for this study was supported by a fund from Universiti Kebangsaan Malaysia (Grant No. DPP-2013-158).

\section{References}

Gopinath, A. (1993). Sejarah Politik Pahang 1880-1935. Selangor: Dewan Bahasa dan Pustaka.

Middlebrook, S. M. (1983). Yap Ah Loy, 1837-1885. Kuala Lumpur: Art Printing Works.

Pahang Annual Report, 1891.

Reid, A. (1967). Nineteeth century pan Islam in Indonesia and Malaysia. Journal of Asian Studies, 25(2), 267-283. http://dx.doi.org/10.2307/2051930

Roff, W. (1967). Origin of Malay nationalism. New Heaven and London: Yale University Press.

Straits Settlement Records India Office. 1892. (9/92).

The Colonial Office Correspondence. (C.O 273/179), (C.O 273/180), (C.O 273/182), (C.O 273/183) \& (C.O 273/184).

\section{Copyrights}

Copyright for this article is retained by the author(s), with first publication rights granted to the journal.

This is an open-access article distributed under the terms and conditions of the Creative Commons Attribution license (http://creativecommons.org/licenses/by/3.0/). 